\title{
Beyond early warning systems:querying the relationship between international law and disaster risk (reduction)
}

Article

Accepted Version

Aronsson-Storrier, M. (2019) Beyond early warning systems:querying the relationship between international law and disaster risk (reduction). Yearbook of International Disaster Law, 1 (1). pp. 51-69. ISSN 2590-0846 doi: https://doi.org/10.1163/26662531-01001005 Available at https://centaur.reading.ac.uk/84489/

It is advisable to refer to the publisher's version if you intend to cite from the work. See Guidance on citing.

To link to this article DOI: http://dx.doi.org/10.1163/26662531-01001005

Publisher: Brill

All outputs in CentAUR are protected by Intellectual Property Rights law, including copyright law. Copyright and IPR is retained by the creators or other copyright holders. Terms and conditions for use of this material are defined in the End User Agreement.

www.reading.ac.uk/centaur 
Central Archive at the University of Reading

Reading's research outputs online 


\section{Beyond early warning systems: Querying the relationship between international law and disaster risk (reduction) \\ Marie Aronsson-Storriert}

\section{Introduction}

There is no such thing as a 'natural' disaster. ${ }^{2}$ Acknowledging that disasters are (largely) social productions invites investigation into the processes through which they are produced. This article explores the role of international law in reducing disaster risk, with a particular focus on the inclusion of disaster risk reduction (DRR) in the 2016 International Law Commission's (ILC) Draft Articles on the Protection of Persons in the event of Disasters (the Draft Articles). Positioning the Draft Articles within the wider emerging body of law, policy and scholarship relating to DRR, the article seeks to shed light on their importance, limits and opportunities. Focussing particularly on Draft Article 9, and contrasting its scope with social understandings of disaster risk, the chapter opens up significant space for enquiries into the role of international law in creating and addressing disaster risk. It is argued that while the inclusion of DRR into the draft articles should be celebrated, the Draft Articles are far from providing a 'coherent framework for disaster risk reduction', ${ }^{3}$ and must not set the outer limits for enquiries into the relationship between international law and disaster risk. Instead, it will be shown how a social understanding of disaster risk ${ }^{4}$ can inform work on international law as it relates to the structural root causes of vulnerability, as well as the way in which our treatment of nature and natural resources affect and create hazards, increasingly diminishing the line between what can be considered a hazard of 'human' or 'natural' origin.

\footnotetext{
${ }^{1}$ I would like to express my gratitude to the editors for inviting me to contribute to this inaugural issue and to the reviewers for their helpful comments. My sincerest thanks also to Adrian Aronsson-Storrier, Karen da Costa, and Matthew Windsor for insightful feedback on drafts at various stages of the writing process. ${ }^{2}$ See, eg, Phil O'Keefe, Ken Westgate and Ben Wisner, 'Taking the Naturalness out of Natural Disasters' (1976) 260 Nature 566; Vijayalakshmi Viswanathan and Anshu Sharma, The Face of Disasters (SEEDS, April 2019) available at https://www.seedsindia.org/THE-FACE-OF-DISASTERS-2019.pdf. See also the campaign 'No Natural Disasters' at https://www.nonaturaldisasters.com/.

${ }^{3}$ As recently suggested by Iceland on behalf of the Nordic states. See UN General Assembly, 'Sixth Committee, Summary record of the $31^{\text {st }}$ meeting' (31 January 2019) UN Doc A/C.6/73/SR.31, para. 25. See also UNGA, 'Sixth Committee, Summary record of the 20" meeting' (11 November 2016) UN Doc A/C.6/71/SR.20, para. 48 .

${ }^{4}$ Defined by the Open- ended Intergovernmental Expert Working Group on Indicators and Terminology relating to Disaster Risk Reduction as '[t]he potential loss of life, injury, or destroyed or damaged assets which could occur to a system, society or a community in a specific period of time, determined probabilistically as a function of hazard, exposure, vulnerability and capacity.' See UNGA, 'Report of the open- ended intergovernmental expert working group on indicators and terminology relating to disaster risk reduction' (1 December 2016) UN Doc A/ 71/644. See section 3 for further discussion on disaster risk.
} 
The argument is set out as follows: The next section introduces the process with which DRR came to be included within the scope of the Draft Articles, with section 2 introducing the scope of the obligations as set out in Draft Article 9. Section 3 then contrasts this scope with a sociological understanding of disaster risk, and a conceptualisation of hazard and vulnerability. Section 4 concludes with a discussion on what this means for the future research agenda on DRR and international law. I argue that it is important to move beyond dedicated DRR measures in order to interrogate the ways in which different areas of international law contribute to, and can be used to prevent and mitigate, disaster risk.

\section{Historical background}

By now, the words of Jean Jacques Rousseau following the 1755 Lisbon earthquake and tsunami are well known amongst DRR scholars, and increasingly also outside of academic circles. ${ }^{5}$ Responding to a poem by Voltaire, where the author had blamed the forces of nature for the disaster(s) in Lisbon, ${ }^{6}$ Rousseau urged him to think again: 'concede, for example, that it was hardly nature who assembled there twenty-thousand houses of six or seven stories. If the residents of this large city had been more evenly dispersed and less densely housed, the losses would have been fewer or perhaps none at all. ${ }^{7}$ He further questioned practices of urbanisation of earthquake prone areas: 'Will we say that the order of the world must change to suit our whims, that nature must be subject to our laws, that in order to prevent an earthquake in a certain spot, all we have to do is build a city there? ${ }^{9}$

Despite these observations being made by Rousseau over 260 years ago, we often still hear the term 'natural disasters' in the media, as well as from organisations involved in disaster risk reduction and response. The use of this term immediately removes the human factor of the disaster and thus the belief that it can be regulated. The dialogue started to change in the disaster studies' field several decades ago, but this change has taken a long time to reach the field of international law. This is not to say that states have been unaware of the

\footnotetext{
${ }^{5}$ See, eg, John D Sutter, 'How to talk About Hurricanes Now' CNN (11 October 2018) <https://edition.cnn.com/2018/10/10/health/sutter-natural-disaster-hurricane-michael/index.html>. ${ }_{6}^{6}$ Importantly, he did so while rejecting the then popular 'act of God' narrative, still present to this day. See, eg, the Russian government's submission in ECHR, Budayeva and Others v. Russia (Apps nos. 15339/ 02, 21166/ 02, 20058/ 02, 11673/02 and 15343/ 02), 20 March 2008, para. 117.

${ }^{7}$ J.A. Leigh (ed.), Correspondence complète de Jean Jacques Rousseau, vol. 4 (Geneva, 1967), 'Rousseau to Voltaire, 18 August 1756', 37-50 (translated by R Spang) available at <www.indiana.edu/ enltnmt/texts/JJR\%20letter.html>. See also Russel R Dynes, 'The Dialogue Between Voltaire and Rousseau on the Lisbon Earthquake: The Emergence Of A Social Science View' (Preliminary Paper \#293, Disaster Research Center, University of Delaware, 1999).

${ }^{8}$ Ibid (Leigh).
} 
human factors of disaster, which is demonstrated, for example, by Article 2 of the 1927 Convention Establishing the International Relief Union (IRU). ${ }^{9}$ The article listed as one of the objectives of the IRU to stated that '...in a general way, to encourage the study of preventive measures against disasters. ${ }^{10}$ While vague, it was at the very least an acknowledgement that there is such a thing as disaster prevention. Still, following the Second World War and the dissolution of the IRU, the regulation of disasters fell off the international agenda, and when it returned decades later, it was limited to disaster response. ${ }^{11}$

It was not until the late 1980s that the need to take preventative measures against disasters was widely recognised, ${ }^{12}$ with the United Nations (UN) General Assembly (UNGA) naming the 1990 s as the International Decade for Natural Disaster Reduction. ${ }^{13}$ In 1991 UNGA Resolution 46/182 stated that '[s]pecial attention should be given to disaster prevention and preparedness by the Governments concerned, as well as by the international community', ${ }^{14}$ and in 1994, 148 states adopted the Yokohama Strategy for a Safer World: Guidelines for Natural Disaster Prevention, Preparedness and Mitigation and Plan of Action. ${ }^{15}$ Since the adoption of the Yokohama Strategy, there has been a significant number of new DRR agreements and policies. ${ }^{16}$

\footnotetext{
${ }^{9}$ Convention and Statute establishing an International Relief Union, 12 July 1927. For details on the International Relief Union, see Peter Macalister-Smith, 'The International Relief Union of 1932' (1981) 5(2) Disasters 147.

${ }^{10}$ Art. 2(2) (emphasis added). See also Lowell Juilliard Carr, 'Disaster and the Sequence-Pattern Concept of Social Change' (1932) 38 American Journal of Sociology 207.

${ }^{11}$ This had, of course, also been the main focus of the IRU. For a more detailed overview of the development of DRR policy in this period, see Marie Aronsson-Storrier, 'Exploring the Foundations: The Principles of Prevention, Mitigation, and Preparedness in International Law', in Katja Samuel, Marie Aronsson-Storrier and Kirsten Nakjavani Bookmiller (eds), Cambridge Handbook of Disaster Risk Reduction and International Law (CUP, 2019) 52, 57-64.

${ }^{12}$ This was also reflected in bilateral agreements. See, eg Republic of Austria and the Federal Republic of Germany Agreement Concerning Mutual Assistance in the Event of Disasters or Serious Accidents, Salzburg, 23 December 1988, especially art. 13; Convention on Mutual Assistance in Case of Catastrophes or Serious Accidents, 21 April 1981, Belgium - France, especially art. 11.

${ }^{13}$ UNGA Res 42/169 (11 December 1987) UN Doc A/RES/42/169.

${ }^{14}$ Ibid, para. 8.

${ }^{15}$ Yokohama Strategy and Plan of Action for a Safer World: Guidelines for Natural Disaster Prevention, Preparedness and Mitigation, 27 May 1994.

${ }^{16}$ In addition to the below, see, eg, Tampere Convention on the Provision of Telecommunication Resources for Disaster Mitigation and Relief Operations, 18 June 1998; International Civil Defence Organisation, Framework Convention on Civil Defence Assistance, 22 May 2000; Association of Southeast Asian Nations (ASEAN), ASEAN Agreement on Disaster Management and Emergency Response, 26 July 2005.
} 
Perhaps most notably, the Yokohama Strategy for a Safer World was succeeded in 2005 by the Hyogo Framework For Action $2005-2015,{ }^{17}$ which in turn was succeeded by the Sendai Framework for DRR 2015-2030. ${ }^{18}$ Alongside the dedicated DRR instruments, although not putting DRR as its central focus, the 2006 Proposal by the ILC Secretariat calling for the 'Protection of Persons in the Event of Disasters' to be included in the work of the ILC, contained a section on 'Disaster prevention and risk reduction'. ${ }^{19}$ Along the same lines, the 2007 Memorandum $^{20}$ acknowledged the 'growing awareness that reliance on the provision of disaster relief merely serves to perpetuate the cycle of recurring disasters, at an increasing social, economic and environmental cost', and that

'[a]ccordingly, the emphasis in recent decades has shifted away from disaster management, concentrating on short-term emergency contingencies, towards the adoption of disaster risk reduction (also known as "disaster risk management") strategies focusing on prevention and mitigation activities which can contribute to saving lives and protecting property and resources before they are lost. ${ }^{21}$

Consequently, Eduardo Valencia Ospina's preliminary report as the Special Rapporteur called for an inclusive approach to the topic. ${ }^{22}$ However, this was not warmly received by all members of the ILC, with some states calling for a complete rejection of the inclusion of DRR 'in order not to overly extend the scope', and other states asking it to be pushed to the future and to primarily focus on disaster response. ${ }^{23}$ Bearing in mind the different views, the Special Rapporteur proposed an initial focus on legal aspects of disaster response, with the view to return to DRR later in the process. ${ }^{24}$ Thus the 'add-on' approach to DRR was born,

\footnotetext{
${ }^{17}$ Hyogo Framework for Action 2005- 2015: Building the Resilience of Nations and Communities to Disasters (22 January 2005) UN Doc A/CONF.206/ 6.

${ }^{18}$ Sendai Framework for Disaster Risk Reduction 2015-2030 (18 March 2015) UN Doc A/ CONF.224/

CRP.1. Adopted by the UNGA in Res 69/ 283 (23 June 2015) UN Doc A/ RES/ 69/ 283.

${ }^{19}$ ILC, 'Report of the International Law Commission on the work of its fifty-eighth session' (1 May-9 June and 3 July-11 August 2006)' UN Doc A/61/10, Annex III, para. 23.

${ }^{20}$ ILC, 'Protection of persons in the event of disasters: Memorandum by the Secretariat' (11 December 2007) UN Doc A/CN.4/590.

${ }^{21}$ Ibid, para. 31 (footnotes omitted). The paragraph further states that: 'The goal is twofold: to build resilience to hazards and to ensure that development efforts do not increase vulnerability to those hazards.' See also the summary in ILC, 'Report of the International Law Commission on the work of its sixtieth session (5 May- 6 June and 7 July-8 August 2008)' (21 January 2009) UN Doc. A/CN.4/606, para. 80.

${ }^{22}$ Eduardo Valencia-Ospina, 'Preliminary report on the protection of persons in the event of disasters' (5 May 2008) UN Doc A/CN.4/598 para. 57.

${ }^{23}$ ILC, 'Report of the International Law Commission on the work of its sixtieth session (5 May- 6 June and 7 July-8 August 2008)’ UN Doc. A/CN.4/606, para. 239 (see also para. 80.)

${ }^{24}$ Eduardo Valencia-Ospina, 'Second report on the protection of persons in the event of disasters' (7 May 2009) UN Doc A/CN.4/615, para. 29. See also Eduardo Valencia-Ospina, 'Third report on the protection of persons in the event of disasters' (31 March 2010) UN Doc A/CN.4/629, para. 7.
} 
with the early Draft Articles not directly mentioning DRR, but leaving the door open for its subsequent inclusion. ${ }^{25}$

DRR first returned to the agenda in the Special Rapporteur's fifth report, which considered international cooperation. ${ }^{26}$ In proposing a draft article on 'the duty to cooperate', it was the intention of the Special Rapporteur that this included cooperation in DRR, ${ }^{27}$ even if it was not explicitly mentioned in the general wording of the later adopted Draft Article 5 bis. $^{28}$ The following year, the Special Rapporteur's sixth report was dedicated to DRR and proposed a specific provision on cooperation for DRR (Draft Article 5 ter), as well as then Draft Article 16 on the duty to prevent. ${ }^{29} \mathrm{By}$ now, the shift in the attitude of states towards an acceptance of an inclusion of DRR into the Draft Articles was evident and both provisions were adopted at first reading (albeit, in the case of Draft Article 16, in a slightly amended version entitled 'Duty to reduce the risk of disasters'). ${ }^{30}$ Both provisions maintained their name and substance when the ILC concluded its work on the first reading in 2014 (renumbered to Draft Articles 10 and 11 respectively). Draft Article 10 was later removed by the Drafting Committee before the second reading, in order better to integrate DRR into the Draft Articles, and thus into the more general duty to cooperate in Draft Article 7. As highlighted by Arnold Pronto, '[t]he effect was to confirm that there wasn't a separate legal obligation to cooperate in matters of DRR, but rather that such cooperation fell within the scope of the general obligation under international law, ${ }^{31}$

Despite some states, including Austria, France, ${ }^{32}$ Islamic Republic of Iran, Republic of Korea and the United States, ${ }^{33}$ raising concerns about the inclusion of DRR in the Draft

\footnotetext{
${ }^{25}$ ILC, 'Report of the International Law Commission Sixty-second session (3 May-4 June and 5 July-6 August 2010)' UN Doc A/65/10, para. 331(4).

${ }^{26}$ Eduardo Valencia-Ospina, 'Fifth report on the protection of persons in the event of disasters' (9 April 2012) UN Doc A/CN.4/652.

${ }^{27}$ Ibid, para. 114.

${ }^{28}$ See ILC, 'Report of the International Law Commission: Sixty-fourth session (7 May- 1 June and 2 July- 3 August 2012)' UN Doc A/67/10, para. 56, fn 275.

${ }^{29}$ Eduardo Valencia-Ospina, 'Sixth report on the protection of persons in the event of disasters' (3 May 2013) UN Doc A/CN.4/662.

${ }^{30}$ ILC, 'Report of the International Law Commission Sixty-fifth session' (6 May-7 June and 8 July-9 August 2013) UN Doc A/68/10, para. 61.

${ }^{31}$ Arnold Pronto, 'The ILC's Articles on the Protection of Persons in the Event of Disasters and Disaster Risk Reduction: A Legislative History' in Katja Samuel, Marie Aronsson-Storrier and Kirsten Nakjavani Bookmiller (eds), Cambridge Handbook of Disaster Risk Reduction and International Law (CUP, 2019$) 71$.

${ }^{32}$ UNGA, 'Sixth Committee, Summary record of the $21^{\text {st }}$ meeting' (22 December 2009) UN Doc

A/C.6/64/SR.21, 4, para. 20; and UNGA, 'Sixth Committee, Summary record of the 17th meeting' (8 November 2013) UN Doc A/C.6/68/SR.17, para. 112.

${ }^{33}$ See Eduardo Valencia-Ospina, 'Eighth report on the protection of persons in the event of disasters' (17
} 
Articles, it should be noted that the majority of states were in support. ${ }^{3 t}$ While states initially had only been discussing whether or not to include DRR in the process, approaching (and following) the adoption of the Draft Articles at first reading, the input became more specific. It should be noted also that during the progression of ILC's programme, the International Federation of the Red Cross and Red Crescent Societies (IFRC) expanded the scope of its highly influential 'disaster law' programme to include DRR in 2012, and further advocated for the inclusion of DRR in the Draft Articles. ${ }^{35}$

During the revision of the Draft Articles as adopted on the first reading, states came together in Sendai, Japan, in March 2015 to adopt the Sendai Framework for Disaster Risk Reduction 2015-2030. Compared to its predecessor, the Sendai Framework demonstrated a significant shift away from preparedness of response, towards addressing the risk of hazards, including clearer acknowledgments of the close relationship between DRR, climate change action and sustainable development. ${ }^{36}$ The adoption of the Sendai Framework was reflected in the Special Rapporteur's proposal to change (then) Draft Article 11 to also include an obligation to prevent the 'creation of new risk' as well as to 'reduce existing risk'. This, however, was met with resistance in the ILC and did not make it into the wording of the Draft Articles as adopted on second reading, although, interestingly, it was included in the commentary. ${ }^{38}$ This was, indeed, also the approach taken by the Special Rapporteur, as well as the Commission, with regard to the Sendai Framework, in order to allow for flexibility and avoid unnecessary dating of the Draft Articles. ${ }^{39}$

\footnotetext{
March 2016) UN Doc A/CN.4/697, para. 193 (and accompanying footnotes).

${ }^{34}$ Including Chile, China, Cuba, Germany, Ghana, Greece, Ireland, Japan, Mexico, Portugal, Poland, Slovenia, South Africa, Thailand, and the European Union. See ibid, paras. 190-191 (and accompanying footnotes). As noted by Pronto, '[t]he position of the Netherlands changed over time from opposition to cautious acceptance'. Pronto (above n 31) 78.

${ }^{35}$ See IFRC, 'Background on the Programme' <https://www.ifrc.org/en/what-we-do/disaster-law/aboutidrl/background-on-the-programme/>.

${ }^{36}$ See, eg, the Sendai Framework, paras. 11-13. See also UNDRR, 'Global Assessment Report on Disaster Risk Reduction 2019' (UN, 2019), section 1.2.

${ }^{37}$ Valencia-Ospina, 'Eighth report on the protection of persons in the event of disasters' (above n 33) para. 212. The revised text for draft art. 11, proposed by the Special Rapporteur, read: Reduction of risk of disasters

1. Each State shall reduce the risk of disasters by taking the necessary and appropriate measures, including through legislation and regulations, to prevent the creation of new risk and reduce existing risk and to mitigate and prepare for disasters.

2. Disaster risk reduction measures include the conduct of risk assessments, the collection and dissemination of risk and past loss information and the installation and operation of early warning systems.

${ }^{38}$ Draft art. 9, commentary, para. 15.

${ }^{39}$ Though not without its complications (see below), acknowledging the importance of Sendai and the UNDRR (then UNISDR) terminology to inform the interpretation of Draft Article 9 seems to be the correct approach.
} 
Despite the previous hesitation, following the second reading, it is clear that most states appreciate the inclusion of DRR into the Draft Articles, ${ }^{40}$ even if there remains some significant pushback against the ILC's suggestion of adopting them as a convention. ${ }^{4}$

\section{DRR in the Draft Articles as adopted on second reading}

The inclusion of DRR into the Draft Articles, while welcome, is perhaps the clearest example of the challenges involved in incorporating progress made in the wider field of disaster studies into an international law instrument. ${ }^{42}$ The mention of DRR in Draft Article 2 means that any reference to 'in the event of disasters' in the Draft Articles also includes risk reduction. ${ }^{43}$ With Draft Article 2 clearly setting out that DRR falls within the scope of the Draft Articles, and that related efforts should 'adequately and effectively meet[...] the "needs" of the persons concerned', as well as 'take place with full respect for the rights of such persons', ${ }^{44}$ the core of the obligations relating to DRR are set out in Draft Article 9, which states that '[e]ach State shall reduce the risk of disasters by taking appropriate measures, including through legislation and regulations, to prevent, mitigate, and prepare for disasters'. ${ }^{45}$

The Commission uses two separate avenues to establish this obligation to reduce disaster risk. First of all, it refers to a significant number of international agreements on DRR, referred to as 'widespread practice of States reflecting their commitment to reduce the risk of disasters ${ }^{96}{ }^{46}$ While the commentary provides a long list of examples, it is noticeable that there is no discussion on the extent to which states have actually engaged with DRR in practice beyond implementing national legislation and incorporating DRR into the national

\footnotetext{
${ }^{40}$ See, eg, UNGA, 'Sixth Committee Summary record of the 31st meeting' (31 January 2019) UN Doc A/C.6/73/SR.31, paras. 24, 28, 29, 35, 44, 60, 62, 64, 77 and 81.

${ }^{41}$ ILC, 'Report of the International Law Commission on the work of its sixty-eight session' (2 May-10 June and 4 July-12 August 2016) UN Doc A/71/10, para. 46: 'the elaboration of a convention on the basis of the draft articles on the protection of persons in the event of disasters'. See also UNGA Res 73/209 (14 January 2019) UN Doc A/RES/73/209.

${ }^{42}$ The definition of disaster in Draft Article 3(a) being another strong contestant, as evident from the commentary to draft article 3(1) para. 3. See also Giulio Bartolini, 'A Taxonomy of Disasters in International Law' in Flavia Zorzi Giustiniani, Emanuele Sommario, Federico Casolari and Giulio Bartolini (eds.), Routledge Handbook on Human Rights and Disasters (Routledge, 2018) 10.

${ }^{43}$ For complications regarding the interpretation of this, see section 3 below.

${ }^{44}$ Draft art. 2, commentary, para. 1.

${ }^{45}$ Draft art. 9(1). The second paragraph reads in full: 'Disaster risk reduction measures include the conduct of risk assessments, the collection and dissemination of risk and past loss information, and the installation and operation of early warning systems.'

${ }^{46}$ Draft art. 9, commentary, para. 5 .
} 
disaster management frameworks ${ }^{47}$ (which, it should be noted, are DRR measures even where they focus on response). Thus, there is - perhaps unsurprisingly considering the nature of the work - a heavy reliance by the ILC (and, indeed, the Special Rapporteur) on verbal practice and the adoption of multilateral, often non-binding, instruments.

Secondly, the obligation is drawn from other areas of international law, in particular International Human Rights Law (IHRL) and International Environmental Law (IEL). While international law for long has been silent about DRR, this is not to say that existing international law does not contain any obligations to reduce disaster risk. ${ }^{18} \mathrm{~A}$ growing body of literature is dedicated to identifying and synthesising DRR obligations in various areas of international law, predominantly IEL and IHRL. ${ }^{9}$ Discussing, for example, positive obligations on states to take necessary steps to prevent the loss of life, ${ }^{50}$ transboundary harm, ${ }^{51}$ or irreversible damage to the environment, ${ }^{52}$ it is consistently held that IEL and IHRL are foundational legal building blocks in relation to DRR. ${ }^{53}$ Recent literature has also highlighted the importance of the right to information and the communication of risk. ${ }^{54}$

\footnotetext{
${ }^{47}$ Draft art. 9, commentary, para. 6 .

${ }^{48}$ It should be noted that international also plays a significant roe in the creation of risk, as discussed below, section 3.

${ }^{49}$ See, for example, Jaqueline Peel and David Fisher (eds), The Role of International Environmental Law in Disaster Risk Reduction (Brill Nijhoff, 2016); Karen da Costa and Paulina Pospieszna, 'The Relationship between Human Rights and Disaster Risk Reduction Revisited: Bringing the Legal Perspective into the Discussion' (2015) 6 Journal of International Humanitarian Legal Studies 64; Tahmina Karimova, 'Sustainable Development and Disasters' in Susan Breau and Katja Samuel (eds.), Research Handbook on Disasters and International Law (Edward Elgar, 2016 ) 177; Tim Stephens, 'Disasters, International Environmental Law and the Anthropocene' in Susan Breau and Katja Samuel (eds), Research Handbook on Disasters and International Law (Edward Elgar, 2016) 153; Giulio Bartolini and Tommaso Natoli, 'Disaster risk reduction: An International Law Perspective' (2018) Questions of International Law (Zoom In) <http://www.qil-qdi.org/wp-content/uploads/2018/04/01 Disaster-Risk INTRO FIN.pdf>; Mirko Sossai, 'States' Failure to Take Preventive Action and to Reduce Exposure to Disasters as a Human Rights Issue' in Flavia Zorzi Giustiniani, Emanuele Sommario, Federico Casolari and Giulio Bartolini (eds), Routledge Handbook on Human Rights and Disasters (Routledge, 2018) 119.

${ }^{50}$ ECHR, Öneryildiz and others v. Turkey (Apps no. 48939/ 99) 30 November 2004; ECHR, Budayeva and Others v Russia (above n 6); Kristian Lauta, 'Human rights and natural disasters' in Susan Breau and Katja Samuel (eds), Research Handbook on Disasters and International Law (Edward Elgar, 2016) 91.

${ }^{51}$ See, eg, Trail Smelter Case (United States v. Canada), Awards 16 April 1938 and 11 March 1941, Arbitral Tribunal Decision, 3 UNRIAA (1941) 1905; ICJ, Corfu Channel Case (United Kingdom v. Albania) (merits) [1949] ICJ Rep 4 (based on Alabama Claims Arbitration 1872); ILC, Draft articles on Prevention of Transboundary Harm from Hazardous Activities, in 'Report of the International Law Commission on the work of its fifty-third session (23 April - 1 June and 2 July - 10 August 2001)' UN Doc A/56/10, para. 97, draft art. 3; ICJ, Pulp Mills on the River Uruguay (Argentina v. Uruguay) (merits) [2010] ICJ Reps 14, para. 101.

${ }^{52}$ See, eg, ICJ, Gabcíkovo- Nagymaros Project (Hungary v. Slovakia) (merits) [1997] ICJ Reps 7, para. 140. ${ }^{53}$ Draft art. 9, commentary, para. 4. See also John H. Knox, 'Afterword: Environmental Disasters and Human Rights' in Jaqueline Peel and David Fisher (eds), The Role of International Environmental Law in Disaster Risk Reduction (Brill Nijhoff, 2016) 453.

${ }^{54}$ Marlies Hesselman, 'Access to Disaster Risk Information, Early Warning and Education: Implementing the Sendai Framework through Human Rights Law’ in Katja Samuel, Marie Aronsson-Storrier and Kirsten
} 
Importantly, while many other parts of the Draft Articles are focused on the relationship between states, Draft Article 9, to a significant extent, concerns domestic measures. DRR is not primarily concerned about whether or not states are obligated to offer or accept external assistance, but is focused around how a state can minimise its own losses, human, economic, and environmental, resulting from hazards. The specific, internal, nature of the duty to reduce disaster risk can be seen in the use of 'each state' rather than 'states'. Setting aside the duty to cooperate, ${ }^{55}$ significant measures such as urban planning, land regulations, environmental regulations, forestation, health and health care systems, education and so on all primarily take place at the national and local level, albeit sometimes relating to international obligations and guidelines. This said, significant national measures involve developing capacities and putting in place preparedness measures, which can often involve agreements and training exercises with other states.

To assess the obligations contained in Draft Article 9 is no straightforward task. The use of the word 'shall' indicates a binding obligation - although the Draft Articles themselves are, of course, non-binding - to 'reduce the risk of disasters'. It is important to note here that, unlike the Sendai Framework, the ILC Draft Articles do not address all harms caused by hazards, ${ }^{56}$ but is only limited to disasters, which in turn are defined in Draft Article 3(a). Here, disaster is defined as 'a calamitous event or series of events resulting in widespread loss of life, great human suffering and distress, mass displacement, or large-scale material or environmental damage, thereby seriously disrupting the functioning of society'. Thus, these are the kind of events which DRR efforts should aim to 'prevent', 'mitigate' or 'prepare' for. While a clear and general line for this threshold to be met is neither possible nor necessarily

\footnotetext{
Nakjavani Bookmiller (eds), Cambridge Handbook of Disaster Risk Reduction and International Law (CUP, 2019) 188; Simon Whitbourn, 'The "Protection of Knowing": The Evolving Concept of Early Warning and States' Obligations to Inform of Disaster Risk and Warn of Disaster' in Katja Samuel, Marie Aronsson-Storrier and Kirsten Nakjavani Bookmiller (eds), Cambridge Handbook of Disaster Risk Reduction and International Law (CUP, 2019) 131.

${ }^{55}$ As discussed above the duty to cooperate includes cooperation of DRR, see Draft Article 7 with commentary. See also Hugo Cahueñas- Muñoz, 'Disaster Risk Reduction Cooperation for the Protection of Persons in the Event of Disasters' in Katja Samuel, Marie Aronsson-Storrier and Kirsten Nakjavani Bookmiller (Eds), Cambridge Handbook of Disaster Risk Reduction and International Law (CUP, 2019) 87.

${ }^{56}$ The Open- ended Intergovernmental Expert Working Group on Indicators and Terminology relating to Disaster Risk Reduction defines hazard as '[a] process, phenomenon or human activity that may cause loss of life, injury or other health impacts, property damage, social and economic disruption or environmental degradation.' See UNGA, 'Report of the open- ended intergovernmental expert working group on indicators and terminology relating to disaster risk reduction' (above n 4). See also below, section 3.
} 
desirable to establish, it does significantly limit the scope of the Draft Articles. ${ }^{57}$ Indeed, the commentary acknowledges that

'[t]he Commission adopted the present formula in recognition of the fact that the contemporary view of the international community, as reflected in several major pronouncements, notably, and most recently, in the Sendai Framework, is that the focus should be placed on the reduction of the risk of harm caused by a hazard, as distinguished from the prevention and management of disasters themselves. Accordingly, the emphasis in paragraph 1 is placed on the reduction of the risk of disasters. ${ }^{958}$

In other words, the obligation under Draft Article 9 is to reduce the risk of disasters, at the same time as it is about reducing the harm potentially caused by a disaster. But it does not go as far as to state that focus should be to address the risk of harm caused by a hazard (which could well, but not necessarily, amount to a disaster). To be clear, this is an explicit acknowledgement on behalf of the ILC that the Commission rejected contemporary thinking around DRR, including as set out in the 2015 Sendai Framework. While not surprising, this is significant, especially as some states have repeatedly referred to the Draft Articles as providing a 'coherent framework for disaster risk reduction' ${ }^{59}$ It is clear from comments by states that the difference in scope is connected with the possibility of the ILC Draft Articles being adopted as a convention, whereas the Sendai Framework is rather considered as providing 'guidance' to states as how best to minimise harm from hazards. ${ }^{60}$

Paragraph 10 of the commentary further states that the reduction of disaster risk 'is achieved by taking certain measures so as to prevent, mitigate and prepare for such disasters', and that 'the duty being envisaged is one of conduct and not result; in other words not to completely prevent or mitigate a disaster, but rather to reduce the risk of harm potentially caused thereby'. The obligation being one of 'conduct, not result' seems an odd coupling

\footnotetext{
${ }^{57}$ On this point, see comments by the UNDRR (then UNISDR) in Valencia-Ospina, 'Eighth report on the protection of persons in the event of disasters' (above n 33) para. 67.

${ }^{58}$ Draft art. 9, commentary, para. 10.

${ }^{59}$ See UNGA, 'Sixth Committee: Summary record of the 31st meeting, 1 November 2018' UN Doc.

A/C.6/73/SR.31 (31 January 2019) para. 25 (and above n 3).

${ }^{60}$ See, especially, recent comments by the US in UNGA, 'Sixth Committee: Summary record of the 31st meeting' (31 January 2019) UN Doc A/C.6/73/SR.31, para. 69. The indication here is that the Sendai Framework is considered a tool for states, rather than an instrument capable of challenging the status quo. As discussed in the final two sections, the same must not be true for future legal enquiries into DRR.
} 
with the duty ' to reduce the risk'. ${ }^{61}$ A better way to phrase it would be that while there exists a duty to take steps to reduce disaster risk, this obligation can be fulfilled even where risk reduction measures may not be sufficient to prevent a disaster from taking place, or even ending up having a significant mitigating impact on disaster losses.

Additionally, the wording of Paragraph 10 does not sit well with the principle of 'mitigation' as defined in Paragraph $16 .{ }^{62}$ According to the definition referred to by the ILC itself, the very use of the word mitigation is an acceptance that some damage will take place, making it impossible to 'completely mitigate' a disaster (the complete avoidance of a disaster would here be referred to as 'prevention'). Again, the wording of the commentary illustrates significant conceptual confusion, which is perhaps not surprising since the obligation 'to prevent, mitigate, and prepare for disasters' is worded in this way as it 'tracks the formula used in major disaster risk reduction instruments, ${ }^{63}$ rather than because of a careful consideration of the meaning of the principles on behalf of the Commission.

The principles are defined by the UN Office for DRR (UNDRR) and later the Open-ended Intergovernmental Expert Working Group on Indicators and Terminology Relating to Disaster Risk Reduction, whose terminology 'illustrates the meaning' of the terms, and is included to clarify the 'purpose' of the DRR measures which states should take. ${ }^{64}$ It is important to acknowledge that while the wording does indeed track previous agreements, the clarity which they seemingly provide masks some significant complexities which must not be ignored. It was clear already from the 2007 Memorandum that the Commission adopted the idea of the measures included in these principles as being specific phases ${ }^{65}$ of disaster risk management (DRM) and taking place on a 'time continuum' ${ }^{6}{ }^{66}$ However, far

\footnotetext{
${ }^{61}$ Emphasis added.

${ }^{62}$ Mitigation is here defined as ' $[\mathrm{t}]$ he lessening or minimizing of the adverse impacts of a hazardous event', see commentary to draft art. 9, para.16. See also UNGA, 'Report of the expert working group on indicators and terminology relating to DRR' (above n 4).

${ }^{63}$ Draft art 9, commentary, para. 15.

${ }^{64}$ Ibid.

${ }^{65}$ Introduced by the US National Governors Association in 1979, see 'National Governors' Association Center for Policy Research, Comprehensive Emergency Management: A Governor's Guide’ (US Government Printing Office, 1979), 12-13. See also, eg, Carr (above n 10).

${ }^{66}$ ILC, 'Protection of persons in the event of disasters: Memorandum by the Secretariat' (above n 20), para. 27: 'Ip]revention, mitigation and preparedness activities lie on different points of the continuum of actions undertaken in advance of the onset of a disaster'. The time continuum is often illustrated through the use of a 'disaster management cycle', where prevention comes first, followed by mitigation (for harms that cannot be fully prevented), in turn leading to preparedness efforts leading up to the 'event', immediately followed by response and later recovery, leading back into prevention of the 'next disaster' and so on.
} 
from all DRR (or DRM) measures fit neatly into a specific phase, and in reality, efforts which are considered as falling within 'prevention', 'mitigation' and 'preparedness' take place simultaneously. ${ }^{67}$ Indeed, in relation to international law, obligations relating to mitigation and preparedness are considered part of the principle of prevention, such as evacuation plans and procedures relating to the prevention to loss of life. What is more, with mitigation defined as 'mitigation of losses', this can - at least to some extent - be accomplished with a rapid and effective response, which has been put in place through preparedness measures. The latter point reminds us about the problems of seeking to draw a clear line between DRR and disaster response, as agreements and regulations around response are important aspects of disaster preparedness. It is, therefore, important to remember that the clarity sought by the inclusion of the principles masks existing complexities not engaged with by the Commission.

Turning to the second paragraph of Draft Article 9, this provides some examples of DRR measures, including 'the conduct of risk assessments, the collection and dissemination of risk and past loss information, and the installation and operation of early warning systems'. It is clear that the Commission considers the measures listed in Draft Article 9(2) to be central aspects of DRR. ${ }^{68}$ In particular, it considers early warning systems to be 'instrumental both in initiating and implementing contingency plans, thus limiting exposure to a hazard' ${ }^{69}$ The Commission moves on to consider early warning systems to be 'a prerequisite for effective preparedness and response', but unfortunately remains silent on how, in relation to 'slow onset' hazards such as droughts, ${ }^{70}$ early warning systems can be instrumental in preventing a disaster from emerging as they can inform and trigger necessary measures of adaptation.

In summary, the inclusion of DRR is a step in the right direction, yet it has significant limitations in terms of both clarity and scope. Its constraint to the reduction of the risk of disasters, rather than a reduction of harm from hazards means that its scope is significantly narrower than that of the Sendai Framework for DRR to which it refers in the commentary. Further to this, the clear conceptual confusion raises significant questions as to the

\footnotetext{
${ }^{67}$ For further discussion on this, see Aronsson-Storrier (above n 11).

${ }^{68}$ Draft art. 9, commentary, para. 19.

${ }^{69}$ Draft Art 9, Commentary para 22.

${ }^{70}$ This despite 'slow-onset' disasters being included in the scope of the Draft Articles, see commentary to Draft Article 3(a) para 4.
} 
functionality of the obligations set out in Draft Article 9. Therefore, rather than providing clarity in relation to exiting legal obligations, the value of Draft Article 9, and of the inclusion of DRR into the Draft Articles more generally, lies in the firm introduction of DRR into the core of the international legal system, in a way in which is not the case with the Sendai Framework. In this way, it can be considered a gateway into an exploration of the role of (international) law in the creation and minimisation of disaster risk.

\section{Conceptualising disaster risk}

In order to reduce - and successfully regulate - disaster risk, we must first pay attention to the nature and causes of such risk. ${ }^{11}$ As discussed below, far beyond technocratic measures reducing the impact of hazards, understanding disaster risk requires us to examine the economic and political structures that regulate the creation and intensification of numerous hazards, as well as the vulnerability to them. While a brief and schematic introduction to the concept of disaster risk, the purpose of this section is to illustrate how DRR is intrinsic into everyday life.

As previously mentioned, over the course of the last few decennia, it has become widely accepted amongst disaster studies scholars to reject the notion of 'natural disasters' in favour of a focus on the social aspects of disaster risk. One particularly helpful conceptualisation for our purposes is the 'pressure and release' (PAR) model introduced by Piers Blaikie, Terry Cannon, Ian Davis, and Ben Wisner in 1994. ${ }^{72}$ The model sets out how 'a disaster is the intersection of two opposing forces: those processes generating vulnerability on one side, and the natural hazard event (or sometimes a slowly unfolding natural process) on the other. ${ }^{73}$ The authors used the now widely cited formula of disaster risk as equaling 'hazard $\times$ vulnerability', coupled by a mapping of the 'progression of vulnerability' which illuminates the processes operating in different levels to contribute to vulnerability of persons. ${ }^{74}$ The processes were divided into 'root causes', 'dynamic pressures' and 'fragile

\footnotetext{
${ }^{71}$ See, eg, Sendai Framework, priority 1, para. 23 ('Understanding disaster risk'). See also Michael D. Cooper, 'Seven Dimensions of Disaster: The Sendai Framework and the Social Construction of Catastrophe' in Katja Samuel, Marie Aronsson-Storrier and Kirsten Nakjavani Bookmiller (eds), Cambridge Handbook of Disaster Risk Reduction and International Law (CUP, 2019) 17.

${ }^{72}$ First published in Piers Blaikie, Terry Cannon, Ian Davis, Ben Wisner, At Risk: Natural Hazards, People's Vulnerability, and Disasters, $1^{\text {st }}$ edn (Routledge, 1994). The model was reproduced in Ben Wisner, Piers Blaikie, Terry Cannon and Ian Davis, At Risk: Natural Hazards, People's Vulnerability, and Disasters, $2^{\text {nd }}$ edn (Routledge, 2003).

${ }^{73}$ Ibid (Wisner et al), 46.

${ }^{74}$ Ibid, 45 .
} 
livelihoods and unsafe locations', with root causes including the 'distribution of power, wealth and resources', whereas '[d]ynamic pressures channel the root causes into particular forms of unsafe conditions', and include land grabbing, deforestation, corruption, overfishing and decline in biodiversity. Following from this 'fragile livelihoods and unsafe locations' are forms of vulnerability, such as lack of natural resources; dangerous locations, unprotected buildings, fragile health, limited education, marginalisation of certain groups and individuals, limited market and credit access and poor social protection (here connected to political resources and disaster preparedness). ${ }^{75}$

Hazards can be of natural or human-made origin, or stem from a combination of human and natural processes. In the PAR model, hazards include events of climatological, geological, biological, ecological and astronomical origin, and there is explicit

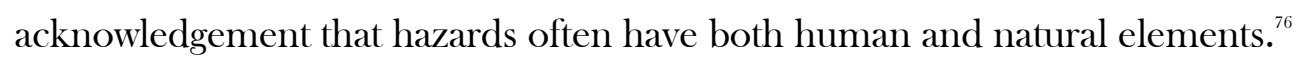

To clarify how 'dynamic pressures' and 'fragile livelihoods and unsafe locations' can affect not only vulnerability, but also the very existence and intensity of hazards, is of particular importance considering the distinction between 'human-made' and 'natural' hazards commonly present in legal texts and analysis. ${ }^{77}$ There is increasing acknowledgment, also amongst legal scholars, that this line has become increasingly blurred during the Anthropocene. ${ }^{78}$ Thus, further to considering the role of law in creating, upholding, and ideally - reducing, vulnerability, we need to consider not only the way in which hazards can be created by human activities, but also how 'natural' hazards can be exaggerated by human activity. The point has been poignantly made in relation to climate change, and the increase of the number and intensity of extreme weather events, adding specific considerations in relation to climate justice. ${ }^{79}$ However, beyond climate change, there is further a need to consider more closely how other activities, such as mining and deforestation, contribute to hazards and how this should inform questions around legal responsibilities and liabilities.

\footnotetext{
${ }^{75}$ Ibid, 47.

${ }^{76}$ Ibid.

The European Court of Human Rights (ECtHR) has further stated that the margin of appreciation of states is larger for 'natural' hazards, as is the threshold of certainty creating an obligation to act. See, eg, Budayeva and Others v. Russia (above n 6).

${ }^{78}$ See, eg, Jacqueline Peel and David Fisher, 'International Law at the Intersection of Environmental Protection and Disaster Risk Reduction' in Jaqueline Peel and David Fisher (eds), The Role of International Environmental Law in Disaster Risk Reduction (Brill Nijhoff, 2016) 1, 3; Lisa Grow Sun, 'Climate Change and the Narrative of Disaster' in Jaqueline Peel and David Fisher (eds), The Role of International Environmental Law in Disaster Risk Reduction (Brill Nijhoff, 2016) 29.

${ }^{79}$ See, eg, Rosemary Lyster, Climate Justice and Disaster Law (CUP, 2015); and Stephens above (n 50).
} 
In other words, there is a need to consider how to conceive of land use and extraction of natural resources which threatens (not to say destroys) nature's own defence systems against natural forces.

An interrogation of the way in which human activities contribute to 'natural' hazards, becomes even more urgent as we consider the effect that climate change has on extreme weather events. Consider, for example, the flooding of Houston following Hurricane Harvey in 2017. There are multiple reports that the pattern and strength of the hurricane (and later storm) was affected by a warming of the Atlantic Ocean attributable to climate change. ${ }^{80}$ However, it was also clear that the way in which the expansion of the Houston population had replaced water absorbing grass with tarmac meant that the rain water had nowhere to go but down the streets (and into people's houses) ${ }^{81}$ In other words, even though floods are often referred to as 'natural' hazards, the Houston floods were partially human made and could have been mitigated.

Nearly 20 years after the publication of the first edition of At Risk, Ben Wisner, together with JC Gaillard and Ilan Kelman, again used the PAR model; this time as part of a conceptualisation of disaster risk which accounts not only for hazards and vulnerability, but also of the capacity of affected persons and communities. Importantly, this updated model also takes into account mitigation efforts conducted by state authorities, including through legislation. ${ }^{82}$ The model is helpful as it illuminates the role that dedicated DRR laws and policies can have on the reduction of disaster risk, while it also demonstrates the limits of legal enquiries which engage only with these aspects and thus fail to recognise how law is not only relevant as a mitigating measure, but is intrinsic in all aspects of disaster risk. ${ }^{83}$ That is, in order to develop a more complete picture of the role of (international) law in addressing and creating disaster risk, it is essential also to explore the role of law in creating,

\footnotetext{
${ }^{80}$ See, eg, US Global Change Research Program, 'Impacts, Risks, and Adaptation in the United States: Fourth National Climate Assessment, Volume II' (2018) chapter 2, box 2.5.

${ }^{81}$ See, eg, Ian Bogost, Houston's Flood Is a Design Problem’ The Atlantic (online, 28 August 2017) <https://www.theatlantic.com/technology/archive/2017/08/why-cities-flood/538251/>.

${ }^{82}$ Expressed as [DR $\left.=\mathrm{H} \times(\mathrm{V} / \mathrm{C})-\mathrm{M}\right]$ (Disaster risk = Hazard $\mathrm{x}$ Vulnerability/Capacity - Mitigation). Ben Wisner, JC Gaillard, and Ilan Kelman, 'Framing Disaster: Theories and Stories Seeking to Understand Hazards, Vulnerability and Risk' in Ben Wisner, J.C. Gaillard and Ilan Kelman (eds), The Routledge Handbook of Hazards and Disaster Risk Reduction (Routledge, 2012) 18, 24.

${ }^{83}$ See also Wisner et al, At Risk (above n 72): 'The most important root causes that give rise to vulnerability (and which reproduce vulnerability over time) are economic, demographic and political processes... [which] are a function of economic, social, and political structures, and also legal definitions and enforcement of rights, gender relations and other elements of the ideological order.' at 47-48.
} 
upholding, supporting or enhancing all aspects of hazards, capacities and vulnerabilities.

As acknowledged by its original authors, the PAR model is neither comprehensive, nor nuanced, but rather a 'simple' illustrative tool. ${ }^{84}$ Yet it is powerful in its simplicity. When considering what the PAR model could add to an analysis of international law and DRR, it is helpful to recall Susan Marks' critique of debates concerning root causes of human rights abuses. Marks argues that '[i]n discussion of root causes, human rights institutions and officials have grappled only partially and rather problematically with the question of why abuses occur, how vulnerabilities arise, and what it will take to bring about change ${ }^{8.5}$ She continues by criticising human rights lawyers of 'halting the investigation of causes too soon', resulting in a failure to account for 'the conditions that engender and sustain' the vulnerability which leads to the abuse. ${ }^{86}$ This failure 'often manifests itself in an emphasis on technical problems and solutions' ${ }^{87}$ Meanwhile, the debate around root causes of disasters, as discussed above, invites - or indeed calls for - an engagement with these larger systemic questions. The PAR model provides a powerful illustration in this regard as it not only produces a list of the root causes of vulnerability, but also positions these processes as part of a narrative, highlighting the role played by foundational structural problems. As argued by John Linarelli, Margot Salomon and Muthucumaraswamy Sornarajah, while '[i]nternational law cannot end underdevelopment or eradicate poverty and unjustifiable material inequality ... it is a precondition of achieving those objectives that the means by which law creates wrongs are removed'. ${ }^{88}$ While international law cannot change the past, we can acknowledge the extent to which it allows for historic inequalities to be transmitted to the present. In the context of DRR, one of the ways in which this can be done is to consider - and correct - the ways in which international law facilitates the transmission of underlying root causes into present day vulnerabilities.

The unpacking and positioning of the root causes of vulnerability and drivers of disaster risk allow us to map the relevant legal and institutional frameworks onto them and thus invites us to examine the role that law plays in every step of this process. In particular, it

\footnotetext{
${ }^{84}$ Wisner et al, At Risk (above n 72), 46. In At Risk, the PAR module is complimented by the 'access model', which focuses more in depth on the processes which create vulnerability.

${ }^{85}$ Susan Marks, 'Human Rights and Root Causes' (2011) 74(1) Modern Law Review 57, 70.

${ }^{86}$ 'Or the focus is turned to the conditions that engender and sustain vulnerabilities, but not to the larger framework within which those conditions are systematically reproduced.' Ibid, 71.

${ }^{87}$ Ibid, 71 .

${ }^{88}$ John Linarelli, Margot Salomon and Muthucumaraswamy Sornarajah, Misery of International Law (OUP, 2018) 1.
} 
clarifies how the role of law in DRR is not just about producing early warning systems, sharing information, or preparing response activities, but also about, for example, the regulation of land use, and the extent to which the law allows for extraction of natural resources by domestic and international actors, and the extent to which laws and policies account for and values the knowledge of, and protect the rights of, local communities, including marginalised groups within such communities. Just as the existing international human rights law system should not be considered an all-encompassing solution for social justice, legal enquiries into DRR shall not stop with technocratic DRR measures such as early warning systems and risk financing, but also need to engage in depth with the political, economic and social aspects of disaster risk.

\section{Beyond early warning systems: Where to from here?}

Following an acknowledgement of the social processes which contribute to disaster risk, the next step is to consider how to turn the 'progression of vulnerability' into the 'progression of safety $^{89}$, and reflect upon the role that law can play in reversing the processes and thus minimise (if not eliminate) disaster risk.

It is clear from the discussion above that DRR goes far beyond the measures suggested in the ILC Draft Articles. Therefore, while it is important to acknowledge the significance if the ILC Draft Articles and the inclusion of DRR within them, it is equally important to be aware of their limits. They may be considered a framework, but they should not be considered as setting the outer frame for future analysis. Still, the inclusion in draft article 9(1) of an obligation to take 'appropriate measures, including through legislation and regulations, to prevent, mitigate, and prepare for disasters' opens a new gateway into potentially powerful explorations of international law.

Although considered to inhabit a barely existing space at the margins of international law, DRR provides a lens through which to explore the way in which international law works to address and to the way in which the world is structured, form the global to the local, including the regulations of 'economical', 'social' and 'political' processes and human interactions with nature. It is therefore essential to explore the ways in which different areas of international

\footnotetext{
${ }^{89}$ The 'progression of safety' is the reversion of the 'progression of vulnerability'. See Wisner et al, At Risk, (above n 72), 344. See also Wisner et al, 'Framing Disaster' (above n 82), 31-32.
} 
law contribute to, and can be used to prevent and mitigate the realisation of, such risk. In this way, DRR can function as a central nexus, allowing us to explore how the various areas of (international) law work together to create and address vulnerabilities and hazards.

Not every legal enquiry or effort needs to address the larger systemic questions; there is significant value in doctrinal analysis supporting the implementation of existing frameworks, including the ILC Draft Articles. But just as it is increasingly accepted that a focus on disaster response does not suffice, we must also accept that DRR efforts which do not address systemic issues will have limited success in addressing disaster risk and minimise losses and suffering which follows when such risk is realized.

Looking ahead, we must move beyond 'practicalities' and consider the extent to which international law facilitates the creation of disaster risk, including regulating the vulnerabilities and capacities of affected persons and communities. That is, while the work to establish and implement existing international obligations to reduce disaster risk should continue, it is also high time to stop and reflect on the questions we are - and should be - asking. In order fully to understand disaster risk, and the role of international law in its creation and reduction, we must delve deeper into the complex processes by which disaster risk is created. This is but a starting point for such a quest. 